\title{
SOCIAL NETWORKS AND \\ RESILIENCE IN THE FIGHT \\ FOR THE RIGHT TO THE CITY: \\ the Movimento Ocupe Estelita, Recife, Brasil
}

\section{REDES SOCIAIS E RESILIÊNCIA \\ NA LUTA PELO DIREITO À CIDADE:}

o MoVIMENTO OCUPE ESTELITA, RECIFE, BRASIL

\author{
Edinéa Alcântara A, B, C, D, E, F \\ Instituto Federal de Educação, Ciência e Tecnologia de Pernambuco, Garanhuns, Pernambuco, Brasil \\ FÁtima FuRTAdo a, e, F \\ Circe Gama Monteiro a, e, F \\ Instituto Federal de Educação, Ciência e Tecnologia de Pernambuco, Campus Garanhuns, Garanhuns, Pernambuco, Brasil
}

Rubenilda Rosinha Barbosa a, E, F

Universidade Federal de Pernambuco, Departamento de Psicologia, Recife, Pernambuco, Brasil

A B S T R A C T : Online social networks have played a key role in the struggle for rights and for more sustainable, less unequal cities. In Brazil, this movement is relatively recent, and has tended to increase in the face of threats or crises that might adversely affect the rights, welfare or life of a city's residents, or the public interest. The Movimento Ocupe Estelita fights against the interests of capital, symbolised by the Projeto Novo Recife, a project destined for the Cais Estelita. The movement started in 2012 and shows signs of resistance and resilience. This article aims to identify the theoretical and empirical basis of this resilience. The research was based on participatory online and offline observation and interviews at the encampment, with a chronology of the occupation process and subsequent campaigns of resistance and struggle. Finally, the movement's capacity to reinvent itself and grow stronger despite continual disputes is analysed.

K E Y W O R D S : right to the city; Direitos Urbanos; Movimento Ocupe Estelita; social networks; resilience.

R E S U M O : As redes sociais têm desempenhado importante papel na luta pelo direito à cidade e no empoderamento da sociedade. No Brasil, esse movimento é recente e surgiu frente a desastres e ameaças aos direitos e à qualidade de vida urbanos. O Movimento Ocupe Estelita luta contra a cidade negociada para atender aos interesses do capital, simbolizada pelo Projeto Novo Recife, um megaempreendimento proposto para o Cais Estelita. O movimento, iniciado em 2012, mostra sinais de resistência e de resiliência. Este artigo objetiva identificar as bases teóricas e empiricas dessa resiliência, a fim de que sirva de reflexão a outras experiências. A pesquisa e a análise foram baseadas em observação participante online/offline e em entrevistas com os acampados. $O$ artigo apresenta uma cronologia dos desdobramentos do movimento no processo de ocupação e as posteriores campanhas de resistência e de luta. Finalmente, analisa a capacidade do movimento de se reinventar e de se fortalecer em face das continuas disputas.

P A L A V R A S - C H A V E : direito à cidade; Direitos Urbanos; Movimento Ocupe Estelita; redes sociais; resiliência.

DOI: https://doi.org/10.22296/2317-1529.2016v18n2p255

Contribution of each author: A. theoretical and conceptual basis and problematization; B. research data and statistical analysis; C. producing figures and tables; D. photographs; E. preparation and drafting of manuscript; F. selection of references 
1 Information available at: $<$ https://direitosurbanos. wordpress.com/>; <https:// www.facebook.com/groups/ direitosurbanos/>; and $<$ https://www.facebook. com/DireitosUrbanos $>$. Accessed on: 14th Dec. 2014

2 The Observatório das Metrópoles developed the index of urban welfare (Índice de Bem Estar Urbano - IBEU), based on three indicators: i) the quality of public services; ii) housing conditions; and iii) urban mobility (RIBEIRO, 2010).

\section{INTRODUCTION}

In various cities around the world, online social networks have played an important role in the struggle for social and political rights and for less unequal and more sustainable cities. Their large communicative potential has made social networks into an essential tool during the emergence of protests, to strengthen citizen participation and for the consolidation of social movements, whose importance is growing across the world against the background of the crisis in representative democracy.

In Brazil, this movement has grown in response to threats against people's rights, welfare and life, as well as the public interest in cities. The June 2013 protests, starting with a cry of indignation against increased bus fares, spread through social networks in various Brazilian cities and emerged as a project of hope for a better life, with demonstrations on the streets of over 350 cities. This movement arose from the mobility crisis in Brazilian cities, motivated by a model of urban growth characterised by property speculation and municipal corruption (CASTELLS, 2013).

In Recife, the struggle for the right to the city is being lead by one of the largest political movements seen amongst urban struggles of recent times in Brazil - the Movimento Ocupe Estelita (MOE). Beginning in 2012, with its roots in the Grupo Direitos Urbanos $\mid$ Recife (DU) ${ }^{1}$, this movement represents the struggle on the part of the city's inhabitants against the interests of those large firms that finance political campaigns and insist on making decisions over major projects, with no democratic participation.

MOE, with its local bases, struggles against the negotiation of the city to suit the interests of capital, as symbolised by the Projeto Novo Recife, and it acquired prominence throughout Brazil and internationally as a result of its protests and especially the occupation of the area of the Cais José Estelita.

The Projeto Novo Recife is a large-scale property development, with 13 tower blocks around 40 storeys high, located at the Cais José Estelita, in São José, a district that has existed for around 500 years and includes a large number of listed buildings as well as being within close reach of low-income communities. A project of this kind is emblematic of the segregationist planning that is being put into practice in the city, which creates barriers, empties public spaces and promotes land occupation, factors that combine to produce the collapse of urban mobility, making the Recife Metropolitan Region second worst in Brazil according to the 2009 urban welfare index (IBEU) $)^{2}$ (RIBEIRO, 2010).

Motivated by the desire to maximise profits, the architecture and planning seen in Recife have given priority to extracting the maximum building potential, leading to the proliferation of fortified enclaves, towers and vertical condominiums surrounded by high walls. This model supposedly aims to guarantee the safety of residents, but it causes the streets to empty out and increases feelings of insecurity. Together with the lack and poor quality of public space, the result is reduced quality of life in the city.

Dissatisfaction with this vision of the city is causing the emergence of a new form of politics to deal with growing urban problems. Social networks allowed the consolidation of a movement with its origins in the Cais Estelita struggle which then transformed itself into a larger movement focused on the right to struggle for the city. 
David Harvey, the author of Rebel Cities, who follows the movement in Recife, emphasises the relevance of similar groups for the emergence of a new politics:

Only when politics focuses on the production and reproduction of urban life as the central labour process out of which revolutionary impulses arise will it be possible to mobilize anti-capitalist struggles capable of radically transforming daily life. Only when it is understood that those who build and sustain urban life have a primary claim to that which they have produced, and that one of their claims is to the unalienated right to make a city more after their own heart's desire, will we arrive at a politics of the urban that will make sense (HARVEY, 2014, p. 21, author's translation).

In Recife, the context of increasing verticalisation and projects having a negative impact on mobility and quality of life created favourable conditions for mobilisation on social networks in the search for more sustainable cities with better quality of life. The reaction to this unsatisfactory city fostered the emergence of social movements such as the DU and the $\mathrm{MOE}^{3}$, which includes the DU and other groups and associations; they are emblematic examples of the struggle against cities mainly organised for the benefit of capital.

The objective of this report is to understand the process by which the movement came into being, its strategies of resistance, and the resilience of social networks while all this was taking place. The resulting understanding is intended to shed light on the whole process and tease out the implications for future struggles.

\section{METHODOLOGY}

This article presents theoretical background drawing on authors who discuss the right to the city and social networks, as well as those treating concepts such as individual, collective or community resilience as psychological and social phenomena present within such processes.

Its analysis and reflections are based on an exploratory study conducted in two realms of participant observation: the online world, especially the Facebook pages of the Grupo Direitos Urbanos | Recife and the Movimento Ocupe Estelita, and the offline world, with the objective of investigating how the Cais Estelita came to be occupied, and the movement's capacity for social resilience in the face of adversity, threats and crises. To this end, texts and interviews were subject to qualitative analysis, an approach well suited to the study's empirical object (ALVES-MAZZOTI; GEWANDSZNAJDER, 2002).

The documentary base for the virtual sphere was made up of posts and comments, text files, photos, audio and video recordings of events and public consultations, events set up by the movements, publicity and campaign materials, all these posted on websites and the groups' Facebook pages. Participation in online discussion groups was used as a tool to articulate, mobilise, and develop communication and organisational/mobilising strategies for the "Occupy" events.

Participation in events in the offline world included participation in various "Occupy" events, public consultations, meetings of Recife's Urban Development Council, attending the Conferência Municipal das Cidades (Municipal Cities
3 Available at: <https:// www.facebook.com/ MovimentoOcupeEstelita>, Accessed on: 14th Dec. 2014. 
40 dia que o Recife foi traído (Available at: <https://www. youtube.com/watch? $v=a z B B \times Q w L R O g \&$ featu re=youtu.be $>$. Accessed on: 17th Oct. 2014); Braço armado das empreiteiras (Available at: <https://www. youtube.com/watch?v=-cw67cCuni0>. Accessed on: 14th Dec. 2014); Ação e Reação (Available at: $<$ https://www.youtube. $\mathrm{com} /$ watch?v=8gFeKTTCTMc\&feature=youtu $. b e>$. Accessed on: 14th Dec. 2014).

5 Vida Estelita (Available at: <https://www.youtube. $\mathrm{com} / \mathrm{watch}$ ? v = bbvKu KutH9w $>$. Accessed on: 14th Dec. 2014).
Conference), organisational meetings for the movements, and regular visits to the occupations at Cais José Estelita and the Viaduto Capitão Temudo (two or three times a week) as well as being present at deliberative assemblies and events organised to attract visitors to the location of Ocupe Estelita and explain the movement's struggle.

Two events were particularly important for an understanding of the resilience of the encamped group: first, the illegal process ${ }^{4}$ by which control of the plot intended for the Novo Recife project was regained by the developers; secondly, shortly after the activists had left the plot, they were pursued by unknown groups of masked men along the Viaduto Capitão Temudo. Individual interviews were conducted, as well as subsequent meetings using the focus group technique, with video and audio recordings that formed the basis of a video 5 to strengthen the movement and publicise the struggle and what the militants had learned during the whole course of these events. Their statements were transcribed to help understand the foundations underlying the resilience of groups that experienced shocks, threats and adversity, as those at the encampment did, and the explosive potential of resilience in the wider context of the city.

\section{THE ROLE OF SOCIAL NETWORKS IN THE STRUGGLE FOR THE RIGHT TO THE CITY}

Social networks acted as a major catalyst of both hope and indignation in the struggle for the city, as "reinventing the city inevitably depends on the exercise of a collective power over the processes of urbanisation" (HARVEY, 2014, p. 28, author's translation).

This concept is fundamental to understanding the mobilisation of the Grupo Direitos Urbanos and the Movimento Ocupe Estelita. David Harvey argues that laying claim to the right to the city implies the ability to interfere radically in the urbanisation process and the way in which cities are (re)produced (HARVEY, 2014).

To understand the social movements that arise in this interface between the online and offline worlds, Castells (2009 quoted in CASTELLS, 2013, p. 10-11) develops a theory of power in his book Communication Power. This form of mass communication, based on horizontal interactive communication networks, is hard for firms and governments to control and grants social actors autonomy by means of a technological platform. In a networked society, autonomous communication is constructed in internet networks and wireless communication platforms, offering the chance to conduct unmonitored discussion of one's actions (CASTELLS, 2013, p. 12, 14).

For Bustamante as well, (2010, p. 15), rather than just being an instrument of social control or a tool for more efficient communication, networks are the battlefield where important struggles for human rights are waged. This power to disseminate information is fundamental in situations that call for mobilisation and communication within the struggle for rights and for quality of life. In Brazil, just $46.5 \%$ of homes have access to the internet (PNAD, 2011; 2013, quoted in IBGE, 2011), although the recent expansion of access to mobile phones and smartphones attained an increase of $112 \%$ in 2015 , a sign of increasing democratisation when it comes to internet access and accessing information. 
The dissemination of communications is a fundamental aspect for any social movement. The scope and speed of transmission through networks has a huge impact on this. Another key aspect for the consolidation of action is a sense of a common struggle. In the case of the struggle for Estelita, the occupation movement emerged as the result of an emotional sense of indignation and revulsion against the authoritarian practices seen in the city.

Castells (2013) emphasises the emotional aspect underlying social movements, which makes them arise when emotion is transformed into action. Drawing on the theory of emotional intelligence, he picks out fear and enthusiasm as the emotions most relevant for social mobilisation. An important factor motivating individuals is their human aspirations for justice, which underlie the struggle for human rights, the protection of minorities, and the struggle against corruption, inequality and authoritarianism. When fear and anxiety are overcome, enthusiasm and hope take over. Low or non-participation of individuals and social groups in the process of reproducing the city causes a feeling of exclusion and the desire to participate in this process, as can be clearly seen in the statement of this young participant in the occupation movement:

[...] I felt really excluded from my city. That's how I've always felt, ever since I was a child. And I didn't understand why that's how things were for me. But then I found out, I got to know the cause of this movement in our city and I became really enthusiastic, but I stayed in the occupation, after I got to know the people, after I felt welcomed by them, when I felt at home with the ideas, I felt I was participating in this city and that was the first time I managed to understand what inclusion was, what it means to feel you are a real person.

Once anxiety is overcome, anger and indignation are the result. If many people suffer from the city's problems, they can transform this anger into action, by means of communication, as soon as they overcome their fear (CASTELLS, 2013, p. 16, author's translation). This statement by an interviewee shows motivation of this kind:

We're here [...] with our baggage, with our history, building this, trying to make this space into one where excluded people can truly say: we're here, we have a voice, we want to change the city, we want to participate in the decisions that shape our city.

Such indignation associated with hope has been the leitmotif of the communication and actions promoted by Direitos Urbanos | Recife and by the Movimento Ocupe Estelita in the struggle for a more inclusive and therefore sustainable city. As one of those interviewed illustrated: "we were brave enough not to give in because of fear or panic, because what it boiled down to was giving up your autonomy because of fear. We also didn't think it was that likely people would come and start a terror campaign.”

Another interviewee showed his indignation about the issues of inequality and exclusion experienced in the city, and saw the solution as lying in people of different social classes joining together to fight for a city that put the interests of people before those of capital: 
[...] so when I arrived here what I found was something completely different from what I was expecting $[\ldots]$ because here, we created ties, we managed to see one another as we really are, and I feel less suffocated here because I like it better here, especially learning from the community, learning with others, because in a classroom we hear the same thing every day and don't really do it. So here we can express our indignation at being suffocated, which is how I felt about the system, people like me who are on the margins of society, like lots of people here. And I thought it was great because I could see the middle class together with people like us who suffer every day $[\ldots]$ suffering violence every day, being evicted from their shacks every day. We're struggling for a compromise, to show the city belongs to the people too, the people have a voice as well. Struggling against this system which makes products and capital more important than life itself.

These individual mechanisms for overcoming fear, adversity, and everyday stress are also associated with attributes and processes relating to individual and community resilience, and so we have turned to studies on resilience to provide a theoretical understanding of the resistance of the Movimento Ocupe Estelita at various stages.

\section{THE MOVIMENTO OCUPE ESTELITA}

The movement to defend the Estelita began in 2012 with its roots in the DU, with more than 31,000 members. DU's focus is the crisis of the city and the dissatisfaction of the population with their quality of life, but it then expanded to embrace the reaction to the Projeto Novo Recife. The DU created a space for online and offline discussion of a project for the city where the citizen would be placed at the centre of planning policy, as a reaction against the unsustainable existing urban development model with its major impact on the city.

From 2012 onwards on Sundays, various \#OcupeEstelita events were held in opposition to the Projeto Novo Recife, with cultural and political activities, inspired by other "Occupy" movements. This was a strategy of protest in the struggle against inconsistent planning decisions and public and private projects of little benefit to the public interest.

The strategy of occupation was also employed on other occasions: \#OcupePrefeitura [occupy the town hall], to apply pressure against the Projeto Novo Recife; \#OcupeEspaçoPúblico [occupy public space] in protest against the privatisation of a square on the side of the "twin towers"; \#OcupeAgamenon, to exert pressure against the viaducts planned to cross Av. Agamenon Magalhães, a major avenue linking Recife to Olinda; \#OcupeMinistérioPúblico to protest against the removal of the Public Ministry official investigating illegalities in this and other high-impact projects in the city of Recife; and \#CoqueResiste, which drew over a thousand people to attend a day of political and cultural activities in the Coque, a low-income community over 100 years old located close to Cais José Estelita which is under constant threat, and has already lost half its territory.

Mobilisation against the Projeto Novo Recife then increased and gained a higher, even international profile on $21^{\text {st }}$ May 2014, when activists encamped to protest at the destruction of warehouses of historical and cultural value on the Cais José Estelita. 
The movement acquired a firm identity with the name "Movimento Ocupe Estelita", which includes the Direitos Urbanos group and other groups and collectives.

During the period militants were present within the land plot, cultural activities were put on at weekends, sometimes attracting over 10,000 people on a single day ${ }^{6}$. The movement grew and attracted allies, because although its struggle was a local one, it reflects a global set of problems - the struggle for the right to the city, to participate in deciding on its future course. The strengthening of the movement was seen in the actors, singers ${ }^{7}$, intellectuals, public figures, local, Brazilian ${ }^{8}$ and international ${ }^{9}$ organisations that joined, as well as the way it captured the attention of the media inside and outside Brazil, especially as a result of the heavy-handed operation conducted by the police with tear gas, pepper spray and rubber bullets, which was condemned in a number of reports and posts.

Figure 1: Support for the movement in Germany

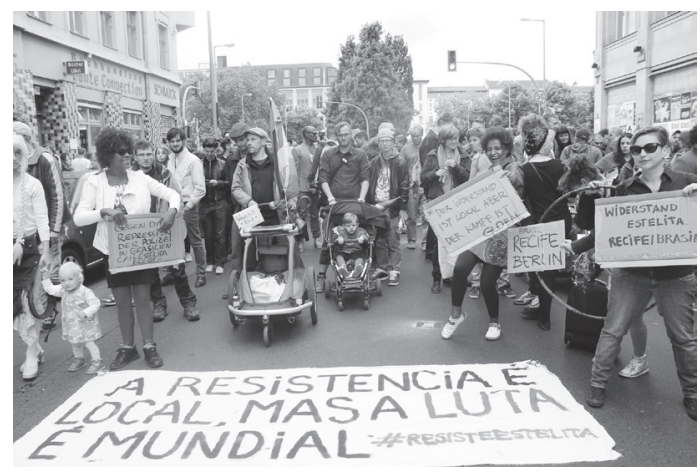

Source: Photo by Sabrina Tenório, International movement of support for the occupation of Cais Estelita.

One of the cultural events held after the period of occupation of the area in question took place on $16^{\text {th }}$ November 2014 (TRUFFI, 2014), and was attended by David Harvey ${ }^{10}$, who said to the movement: "I write about the right to the city, and you do it. This is the most important thing". (Figure 3).

The occurrence of these events provides an important example of key characteristics of community resilience, the capacity to organise and mobilise people and other resources inside and outside the community in order to face adversity and crises. It is significant that on the night of $17^{\text {th }}$ June itself, after the earlier attack by the police, the activists began to set up barricades underneath the Viaduto do Capitão Temudo, in close proximity to the disputed plot of land. This shows both their capacity for resistance and also their resilience, immediately following a shock.

A similar event is the occupation of the central offices of the Prefeitura (town hall) of the city of Recife, when the movement demanded to be included in negotiations to reconfigure the project on the basis of a planning framework that was not considered in the earlier version of the project. This occupation forced the city council to conduct a renewed dialogue with the movement, which returned to the negotiating table.
6 o dia que o Otto cantou no Estelita (Available at: <https://www.youtube. $\mathrm{com} / \mathrm{w}$ at ch? $\mathrm{v}=\mathrm{Xd}$ y u cYogaJl>. Accessed on: 14 Dec. 2014).

7 Criolo Ocupa Estelita Sangue no Cais (Available at: <https://www.youtube. $\mathrm{com} / \mathrm{watch}$ ? v $=\mathrm{GQ} 8 \mathrm{xl}$ BGSWQ>. Accessed on: 14 Dec. 2014); Karina Buhr no Ocupe Estelita - Som na Rural (Available at: <https:// w w w. you tube.com / watch?v=wUCPNqVs6d4>. Accessed on: 14 Dec. 2014); Lirinha no Ocupe Estelita - Som na Rural (song: Memória) (Available at: <https://www.youtube. com/watch?v=m Nm6ZLSDXOW>. Accessed on: 14 Dec. 2014); Lirinha no Ocupe Estelita - Som na Rural (Matadeira) - in this video, Lirinha alludes to Canudos and the massacre that occurred there in the past and their resistence, drawing a comparison with the events at Cais Estelita (Available at: <https://www. youtube.com/watch?v=4NS0t7pz9MQ>. Accessed on: 14 Dec. 2014); Arquitetura de Vertigem - China (Available at: <https://www youtube.com/watch?v=T_ DEREQNgnk>. Accessed on: 14 Dec. 2014).

8 Cf. Lins (2014), Melito (2014) and Sakamoto (2014).

9 Cf. Cais (2014), Les Occupants (2014), Meireles (2014), Senra (2014), Temos (2014) and Watts (2014).

10 David Harvey @ \#OcupeEstelita (Available at: <https://www.youtube $\mathrm{com} / \mathrm{w}$ a t ch ? v = D x W InT8XHk>. Accessed on: 14 Dec. 2014); Pinto (2014). 
Figure 3: David Harvey at the Ocupe Estelita

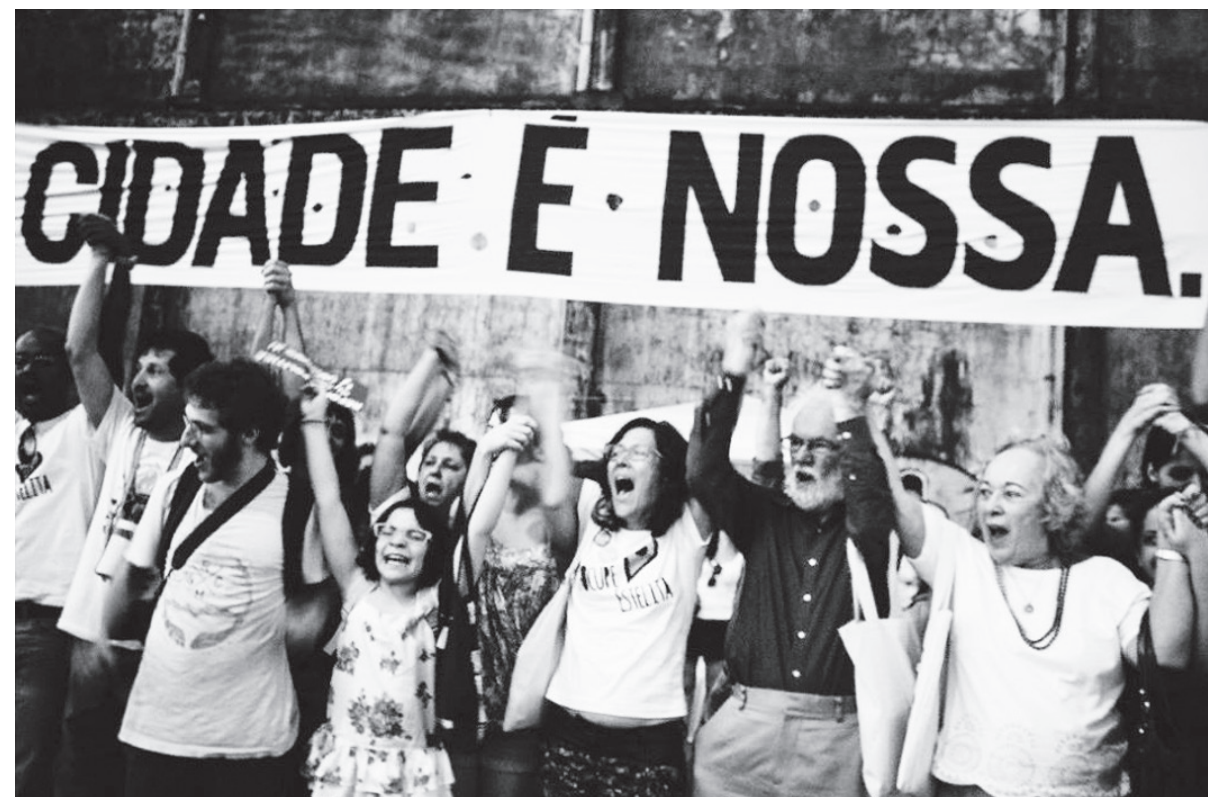

Source: Photo by Leonardo Cisneiros (Available at: <https://www.facebook.com/photo.php?fbid $=757645614306118 \&$ set $=0.233491833415070 \&$ type $=3 \&$ theater $>$. Accessed on: 15th Dec. 2014).

A public consultation was held on $17^{\text {th }}$ July during which the city council presented the guiding principles for the redrafting of the project and heard suggestions. One month later, new proposals were released to the press without being presented first to the society and institutions that had demanded changes in the project, and they showed little change from its original conception, retaining a similar format and the characteristics of segregation from the surrounding city (Figure 4).

Brazil's federal constitution, the Cities Statute and Recife's Master Plan all guarantee the principles of participatory democracy, which were not properly applied by public officials or the developers in relation to the project; or of they were, this was only after they were required by a court order to do so, as in the case of the public consultation meeting set for $14^{\text {th }}$ November without the required notice, which was suspended by order of the court upon a challenge by militants.

This meeting was delayed till $27^{\text {th }}$ November, as a mere formality. Nonetheless, showing the capacity of the movements to have recourse to their rights, the militants took the opportunity to express their indignation over the token participatory process put in place by city administrators in relation to the project, when it became clear that there was no intention to listen to the recommendations presented, as could be seen from the fact that previous suggestions had not been incorporated in the supposedly new project.

On this occasion, an official from the Federal Public Ministry presented various

11 Recife, cidade roubada (Available at: <https:// www. youtube.com/ watch?v=dJY1XE2S9Pk\&feature=youtu.be>. Accessed on: 14th Dec. 2014). illegal features of the project relating to the location of the proposed construction on railway land of historic value, meaning it would be legally impermissible to implement the new version. On this basis, the movement strengthened its advocacy of a complete change in the basis of the project, launching the video Recife, cidade roubada ${ }^{11}$ during the occupy event held on $16^{\text {th }}$ November 2014, which has been viewed over a million 
times; this is a further example of the movement's clear capacity to react positively to adverse events.

Figure 4: Simulation of the proposed remodelling presented at Recife Town Hall

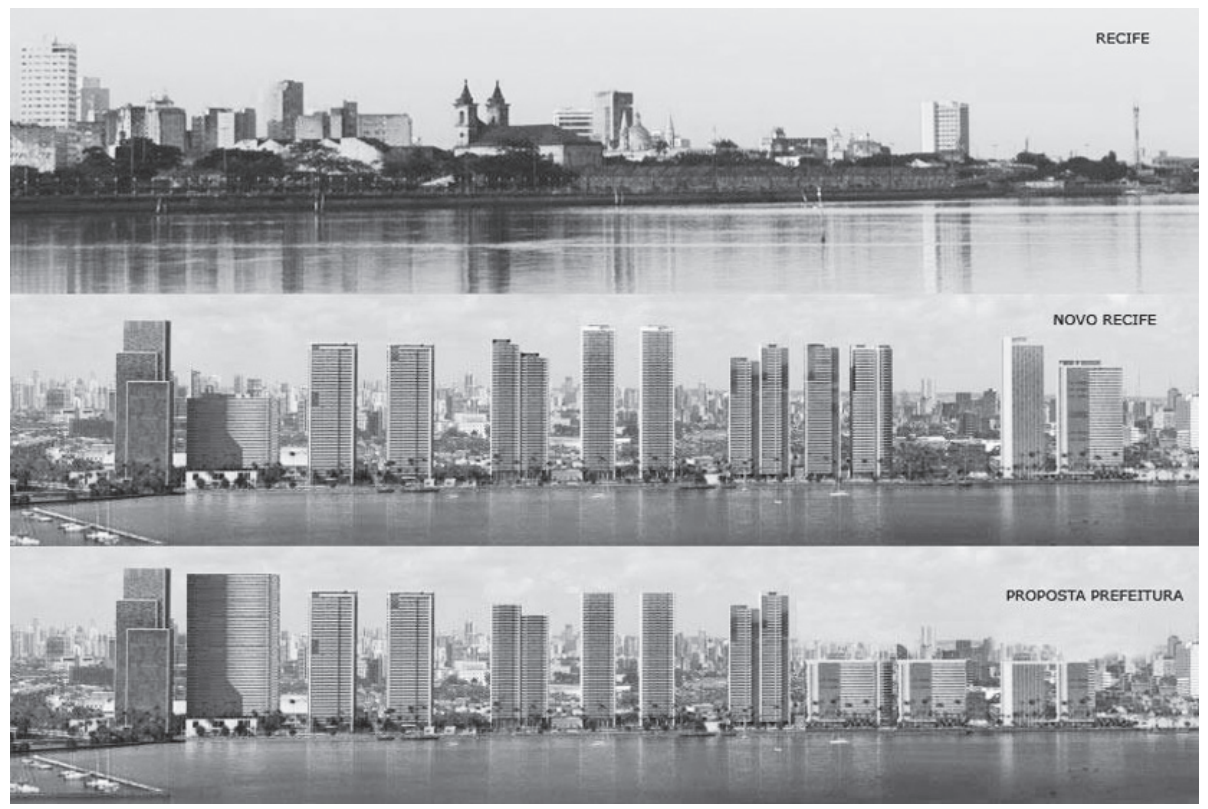

Source: Montage by Theo Araújo (Available at: <https://www.facebook.com/MovimentoOcupeEstelita/photos/a.320104821469838.1073741828.320033178143669/374181602728826/?type $=1>$. Accessed on: $16^{\text {th }}$ Sep. 2013)

The approval and ratification of Law n $08 / 2015$, regarding the Local Plan for the Cais José Estelita, Santa Rita and Cabanga, was accompanied by allegations of illegality, including a legal challenge by Pernambuco's Public Ministry. As a reaction, militants began a series of walks (Figure 5) including the occupation of the Rio Mar shopping mall, and they encamped in front of the mayor's house because they perceived his unwillingness to discuss the Projeto Novo Recife with society. During one of these walks, which had started from Boa Viagem, the militants stopped in front of the offices of Moura Dubeux, leader of the Novo Recife Consortium, and projected the video Novo Apocalipse Recife $e^{12}$, a sharp satire on the alliance between the city council and developers; it has been viewed by more than half a million people and went viral on WhatsApp.

On 30th September 2015, the Federal Police announced the detection of fraud in the auction of the Cais José Estelita land plot in 2008. This was in the context of the operation Lance Final, an investigation into the São Paulo company Milan Leilóes, with links to the Caixa Econômica Federal [a major public banking institution in Brazil], various politicians, the Novo Recife Consortium, and the company Moura Dubeux. On this date, computers, spreadsheets and documents were seized as evidence of the fraud in the auction as well as other crimes including criminal association, sale of influence and active and passive corruption, according to G1 (PF, 2015). This occurred on the eve of the Urban Development Counsel's meeting to approve the Projeto Novo Recife. The meeting was temporarily suspended because of the political context. On the following day, the militants held an act of commemoration, which was very well-attended.
12 Novo Apocalipse Recife (Available at: <https:// www.youtube.com/ watch?v=uE0wJi6xNBk>. Accessed on: 29 Aug. 2015). 
Figure 5: Walk after the approval and ratification of $\mathrm{n}^{\circ} 08 / 2015$, covering the Local Plan for the Cais José Estelita, Santa Rita and Cabanga

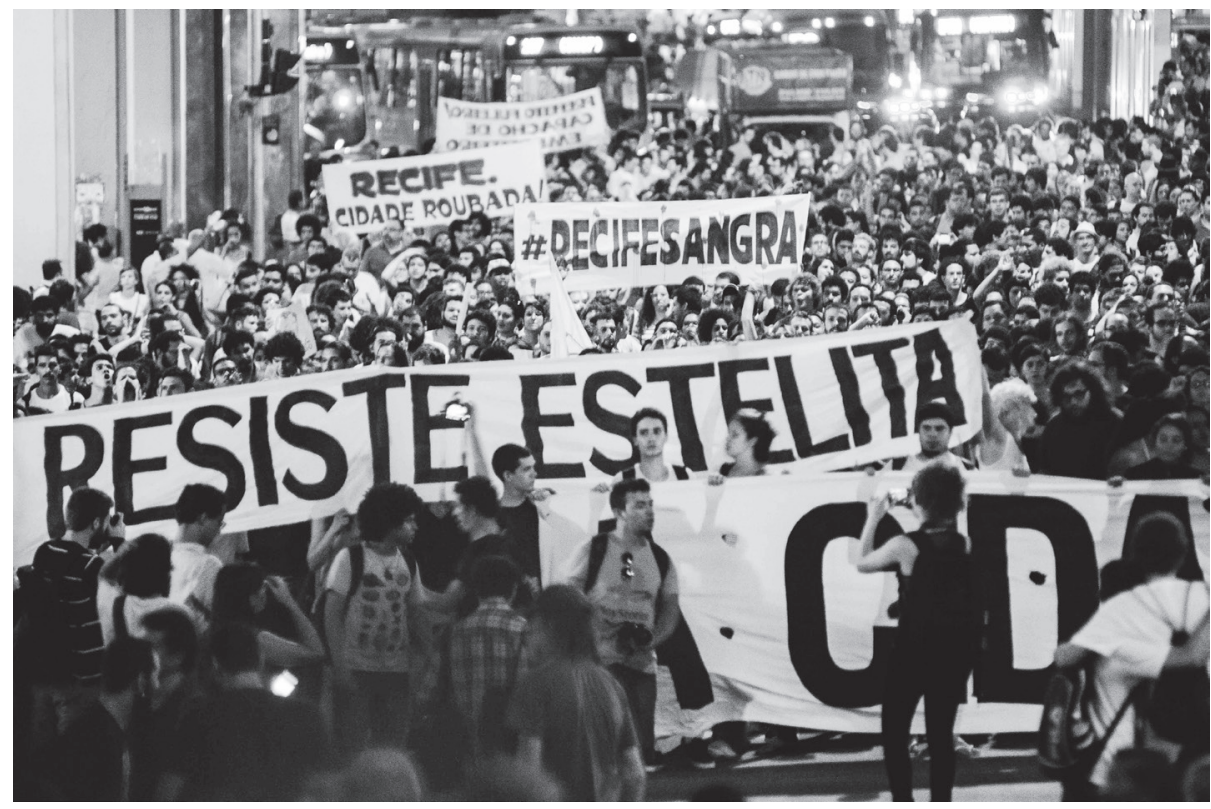

Source: Photo by Marcelo Soares (Available at: <https://www.flickr.com/photos/direitosurbanos/17365571966/in/album-72157652408265225/>. Accessed on 14th Dec. 2014).

On $28^{\text {th }}$ November 2015, the struggle for the Estelita won another major battle when the auction of the quay was annulled by a federal court. As well as giving legal justifications for the annulment of the auction, the judgment emphasises the historic importance of the quay for the city and for future generations, aspects central to the struggle over more than three years: "[...] there is far more of history, landscape, the environment and social and political value to be protected than the ever pressing economic interests of those currently favoured by fortune, all too often allied with elements of public authority." The judge also alleges that "[...] there is no point defending the legality of this absurd misappropriation of real estate resulting from a spurious relationship between the public and private sectors depending on the circumstances

13 The full text of the judgment is available at: <https://www.facebook. com/groups/direitosurbanos/869724339791813 /?pnref=story>. Accessed on: 13th Dec. 2015. of form and content that indubitably mark this pseudo-legal operation."13 The ruling also requires the land be returned within 30 days and orders the authorities not to authorise any more works there. To celebrate these victories, another occupation of the Cais Estelita was held on Sunday 30 ${ }^{\text {th }}$ November 2015, with over 1500 people who responded to an announcement the day before. That night, more than 200 people once again entered the land plot under dispute, as a political act reclaiming the land for society; some of the walls separating it from the quay were breached (Figure 6). 
Figure 6: Militants occupy the Cais Estelita once more

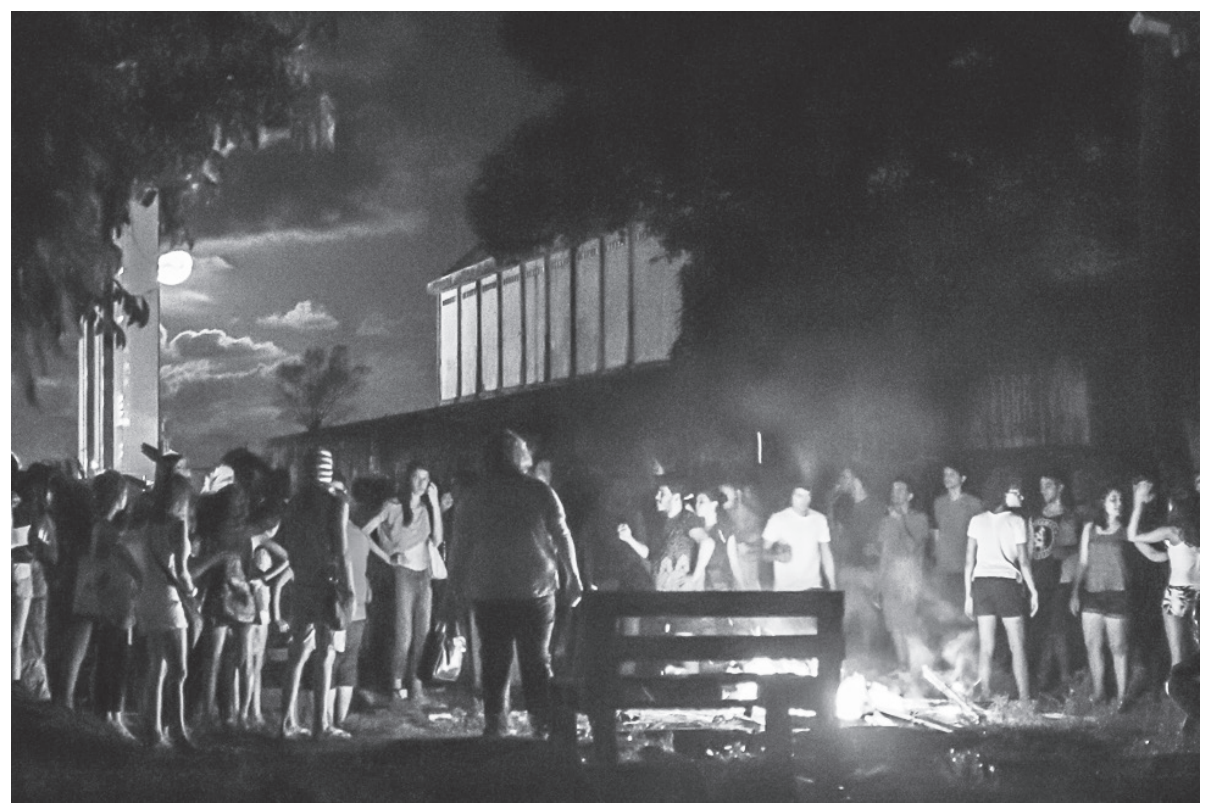

Source: Photo by Keila Vieira.

In sum, the group Direitos Urbanos $\mid$ Recife took a number of opportunities to contribute towards the right of the population of Recife to their city. In the case of the Movimento Ocupe Estelita, the close link between the use of social networks and resilience was particularly clear. From the start of the struggle in 2012, many gains were achieved in the struggle for the right to the city. In broad terms, online mobilization had a concrete impact on the offline world in these respects:

- Mobilisation of civil society for protest, petitions, investigating illegalities, cooperation with the Public Ministry;

- Legal actions and the struggle for integrated planning, a more human city, increased public space, preservation of urban memory and the environment, improved mobility, transparency and social control;

- Online organisation to mobilise for offline events and online discussions of urban problems and major projects;

- The struggle against gentrification (ALCÂNTARA et al., 2013);

- Above all, the consolidation of a local political force made up of militants, both able to bring to bear technical and scientific knowledge in different areas and also the inclination to struggle on the part of battle-hardened young militants, ready to face up to biased decisions, irregularities, and the violation of rights, all within the struggle for the right to the city

The online communication skills of the most active militants are fundamental for motivating and sustaining engagement in the struggle for the right to the city. In this way, they proved able to bring people together, organising them in groups that grew in a short period of time and deal with specific questions related to improving the quality of life in cities, rapidly mobilising creativity, critical capacity, intelligence and knowledge of the city's problems (ALCÂNTARA et al., 2013). 


\section{RESILIENCE AS THE KEY TO READING AND UNDERSTANDING THE RESISTANCE OF THE OCUPE ESTELITA}

Recent decades have seen considerable discussion of the concept of resilience. It is traditionally associated with the capacity of a system to absorb disturbances and reorganise itself when it is subject to change, while retaining the essential aspects of its functions, structure, identity and mechanisms (WALKER et al., 2004).

The report of the UN General Secretariat's High Level Panel on sustainability, "Resilient People, Resilient Planet: A future worth choosing", by including the term resilience in its title, shows its wide dissemination as applied to human beings and their collectivities as well as locations as such.

In the Social Sciences, the use of the term has gradually been extended to the area of human relations in a social context. In this way, it has been used to describe the adaptive capacity of both individuals (BONANNO, 2004; BUTLER; MORLAND; LESKIN, 2007), and communities (ADGER, 2000; BROWN; KULIG, 1996, 1997; SONN; FISHER, 1998; GODSCHALK, 2003). Walsh (2003, p. 4 quoted in LANDAU; SAUL, 2002, author's translation) defines resilience as "[...] the capacity to react to adversity, grow stronger and acquire more resources. It is an active process of resistance, self-recovery and growth in response to the crisis and the challenge."

The emergence of certain psycho-social, cultural and environmental conditions allows individuals, groups and communities to develop resistance and the capacity to face the adversity that may arise, coming out of the conflict all the stronger.

Grotberg (2005, p. 16-17, author's translation) sums up the basis of resilience in the affirmations "I have" (support from people I trust); "I am" (associated with the development of internal psychical strength, being loved, loving and respecting others, taking responsibility for one's actions, having confidence on the future); "I can" (gaining interpersonal skills and resolving conflict, facing up to problems, and finding support from others). An individual who brings together these qualities has a large potential for resilience and the capacity to learn from adverse experiences.

Drawing on a study by Kotliarenco, Cáceres e Fontecilla (1997) on resilience, Melillo (2005, p. 60-61) sums up the qualities of the resilient individual as follows:

1. the ability to cope with adversity, adapt, recover and have a productive life;

2. a history of successful adaptation when exposed to risk or stressful events, while retaining low susceptibility to subsequent stressful events, as well as the capacity to cope effectively with stressful circumstances;

3. the universal human capacity to deal with adversity, overcoming it or being transformed by it, where resilience is one part of the evolutionary process, and needs to be encouraged from childhood on;

4. the capacity to reproduce essential positive behaviour, together with the conjunction of social and mental processes that allow for a healthy life even under chaotic circumstances;

5. a combination of factors that allow problems to be faced and overcome, as the product of environmental factors, temperament and cognitive ability;

When the work of these theoreticians is brought to bear on analysing the case at hand - the Grupo Direitos Urbanos and the Movimento Ocupe Estelita - the 
characteristics present in the theory can clearly be seen, both during the struggle and while coping with stressful situations, and in the words of various individuals.

For example, one of the interviewees reveals the empowerment resulting from having participated actively while overcoming adversity:

[...] the feeling of satisfaction because you were able to contribute to a better project for your city. Feeling capable and active within decisions being made about your city, your area, your region. You end up developing more self-esteem, a greater concept of democracy and justice. You end up regaining your awareness all round, and that's really good, it makes a person feel more whole.

As Melillo (2005, p. 61, author's translation) points out, it is important to notice that "[...] resilience is produced as a function of social and psychological processes. People are not born resilient, and resilience isn't acquired 'naturally' during development: it depends on certain qualities of the iterative process of the subject with other human beings, which is responsible for creating the human psychical system". It is thus within intersubjective interaction that the possibility is found to develop psychological processes which, in combination, create the conditions for building resilience, whether that is of the individual or the group. The literature (ALCÂNTARA et al. 2014) also emphasises that resilient community leaders tend to propagate resilient behaviour within the groups where they are active, contributing to community resilience, whether in the face of day-to-day stress or in extreme situations.

Just as in the case of individuals, it can be observed that resilience on the level of communities also depends on the capacity to mobilise internal and external resources - whether material or immaterial - in order to react positively to adverse events. The notion of resilience thus entails the idea that certain conditions encourage the capacity to resist and cope with adversity. This approach suggests that in order for the resilience of a given community to be strengthened, it is necessary to understand its sociocultural context and the relationships between people and with the environment within which they live while attempting to identify and build up those factors associated with the capacity to mobilise individual (psychological) and collective (community) resources.

Brown and Kulig (1996, quoted in NORRIS et al., 2008, p. 129, author's translation) in their analysis of factors associated with the mobilisation of such individual and group factors define resilience as "the ability to recover from or easily adapt to adverse events or a continually stressful life". Ganor and Ben-Lavy (2003 quoted in NORRIS et al., 2008, p. 129, author's translation) analyes it as "the ability of individuals and communities to cope with a continuous, long-term state of stress".

It seems that community resilience results from a complex juxtaposition of conditions, attitudes and actions bringing positive results and enabling the community to face difficulties. Ojeda (2005, p. 50) identifies some key elements of resilience understood in this way:

1. Collective self-esteem - a prideful attitude and feelings in relation to the place people live;

2. Cultural identity - the incorporation of customs, turns of phrase, dance, or songs that become inherent components of the group;

3. Social humour - the capacity of some groups or collectivities to find comedy in 
the midst of their own tragedy;

4. Records of existing personal and collective resources;

5. Capacity to (re)organise strategy and tactics when needed;

6. Adequate government administration and collective or state probity - decent and transparent handling of public roles.

\section{THE STRENGTH OF VISUAL IMAGES AND SATIRE WITHIN THE MOVEMENT'S COMMUNICATIONS}

Humour has been a significant ally as one creative approach to overcoming adversity. For example, Vanistendael (1994, quoted in OJEDA; AUTLER, 2006, p. 276) emphasises the importance political jokes have played in resisting dictatorships. Wuerfelle, DeFrain and Stinnett (1990, quoted in WALSH, 2005, p. 64) point out the benefits of humour in drawing attention to incongruous aspects of an anxious, inconsistent, bizarre, crazy or illogical situation. In the case studied here, there were numerous jokes within the struggle for the Estelita, whether images and videos or artistic and cultural expressions such as the Carnaval "bloco" Empatando tua Vista.

Figure 7: Satire showing simulated versions of the Projeto Novo Recife in other cities around the world
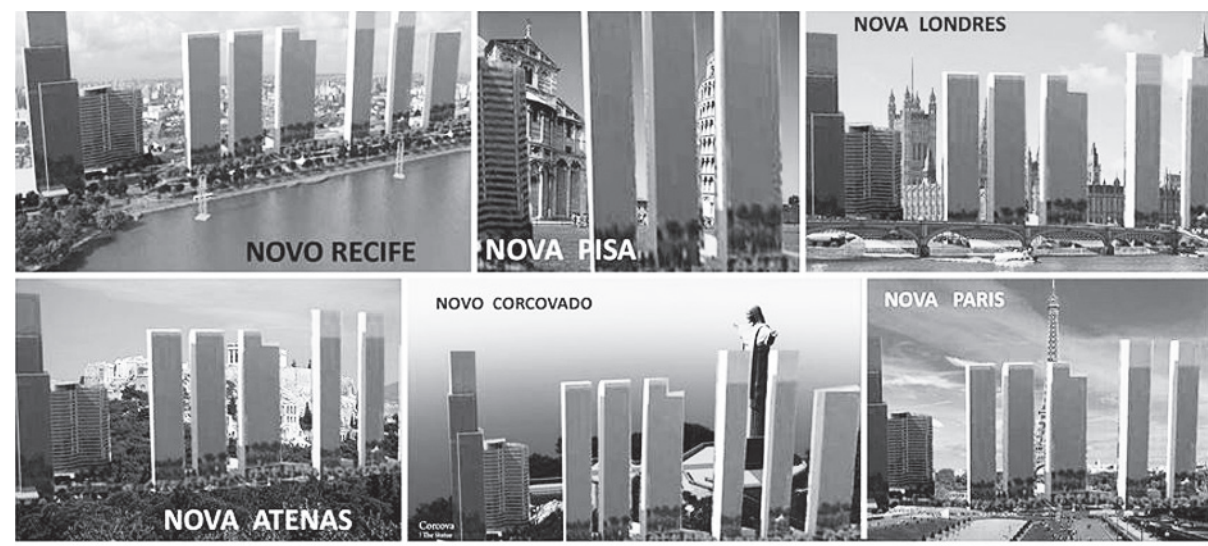

NOVO CORCOVADO
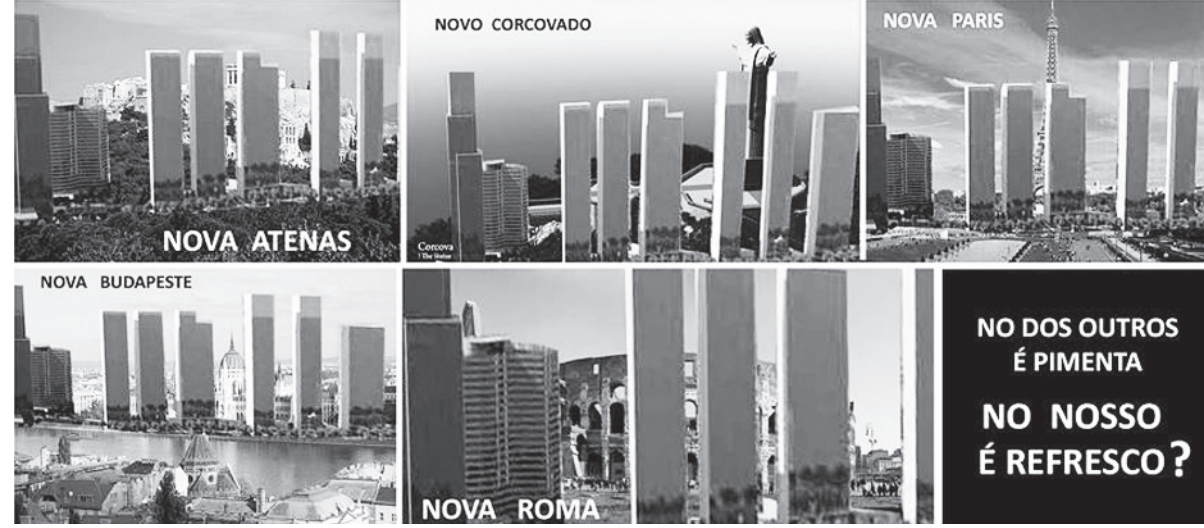

NO DOS OUTROS

É PIMENTA

NO NOSSO

É REFRESCO?

Source: Montage based on Tumblr Projeto Novo Recife (Available at: <http://projetonovorecife. tumblr.com/>. Accessed on: 15 $5^{\text {th }}$ Dec. 2014). 
Figure 8: Carnaval group Empatando tua vista showing the "Twin towers"

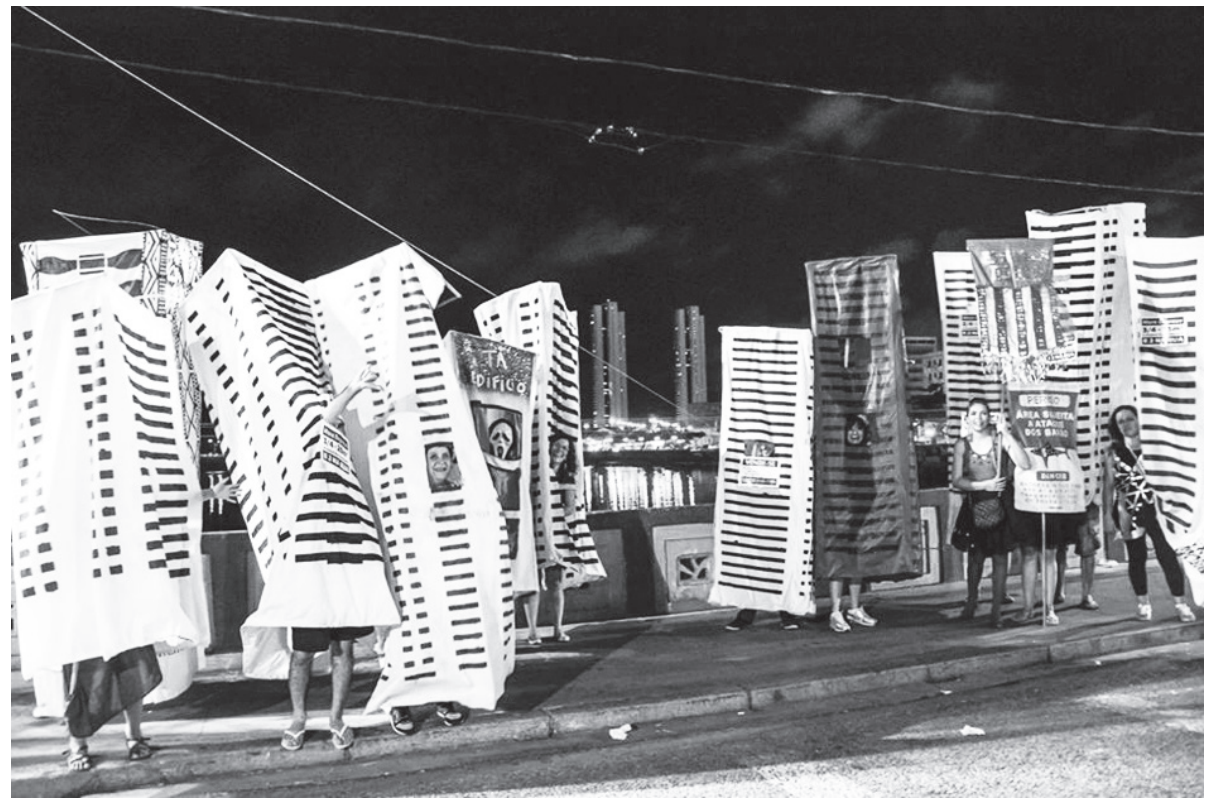

Source: Photo by Ana Lira (Available at: <https://www.facebook.com/empatandoatuavista/ photos/pb.410103215801160.-2207520000.1418611468./412335228911292/?type=3\&theater $>$. Accessed on: 15 Dec. 2014).

This group, which began during Recife's 2014 Carnival, presented an irreverent satire on the city's verticalisation, with people dressed as tower blocks, and was well received by the population. ${ }^{14}$ It was created by residents of the city and militants belonging to the Grupo Direitos Urbanos | Recife to express their indignation and sadness at the trend caused by the city administration's submissiveness to property capital. Wearing fabric prisms, to create the same impression as identikit skyscrapers, carnival-goers attempted to imitate what was occurring in Recife, with the height of the towers growing ever greater, preventing much of the population from enjoying the city's most important views and perspectives (ALCÂNTARA, 2014)

Walsh (1998, quoted in RAVAZZOLA, 2005, p. 81) presents some other aspects important for the development of resilience: recognising problems and limitations that need to be faced, and communicating these frankly and clearly; making a record of existing personal and collective resources; (re)organising strategy and tactics when necessary; and reviewing and analysing losses and gains.

The authors would like to add, however, that in addition to the presence of these qualities in social subjects, community resilience requires the presence within their relationships of attitudes that show emotional support and conversations that allow shared meanings to be built up around negative occurrences, with a narrative that lends dignity to the protagonists.

During the research process on which this article is based, it was noted that some participants within the movement were already familiar with the concept of resilience, while others discovered it when they were interviewed individually, but in both cases they recognised themselves as being resilient. At the level of the group, participants identified in the Movimento Ocupe Estelita some of the characteristics attributed by WALSH (2005) to groups and to the family, for example: a positive perspective on overcoming
14 Video of Troça Empatando tua Vista (Available at: $<$ http://www.youtube.com/ watch?v=P2RgkZkw2AE>; <https://www.facebook com/empatandoatuavista>. Accessed on: 14th Dec. 2014). 
adversity, trying to produce meaning from it; facing crisis as an understandable and manageable challenge; active initiative and perseverance; the courage to face challenges and encourage others; keeping up hope and an optimistic view; confidence that obstacles will be overcome; seeking out new possibilities for inspiration through creativity.

A number of those interviewed referred to trust within the group as one of the factors that helped overcome difficulties and face challenges. One stated that "we created a link of trust, in one another [...] and we learn, we develop knowledge we already had, or discover things we didn't realise we knew, as part of constantly trying to make things better here in this place."

Characteristics of resilient individuals and groups were seen such as: change through learning; a commitment to help others; social responsibility; flexibility, and respect for individual needs, differences and limitations; a connection in the form of mutual help, cooperation and commitment; resolving problems and conflicts collaboratively; and above all, the capacity to mobilise social and economic resources.

Our research on Movimento Ocupe Estelita showed that online communication deserves to be emphasised in the articulation and mobilisation of people, resources and the media, because the production of video and graphical materials improves and increases the impact, drawing people and institutions to support the cause. In her study of communication patterns that help family life run more smoothly, WALSH (2005) points out some other key elements of effective communication within a group which were also seen in the case of the Movimento Ocupe Estelita, such as clarity of messages, avoiding ambiguity; open emotional expression, involving the sharing of a broad range of feelings (happiness and suffering; hopes and fear), as well as the clarification of ambiguous information and the search for truth, through pleasant, good-humoured interactions.

Nonetheless, the heterogeneous nature of the groups, individual vanity, and differing interests or political and ideological positions led to conflict, tension and disputes over power and leadership, all sometimes brought initiatives to a standstill or put people off. Despite this, the strong emotional involvement of the militants and their commitment to the struggle meant they were able to respond rapidly. There are many challenges and this may help with the learning process about how to overcome these internal difficulties. The same resilient characteristics of the movement and its rapid response capacity in extreme situations are strong allies for the growth and maturing of the Movement in its leadership of the struggle for the right to the city, as well as other urban struggles.

\section{FINAL CONSIDERATIONS}

The Movimento Ocupe Estelita came into being in 2012, with its roots in the Grupo Direitos Urbanos | Recife, and expanded with the inclusion of other groups. Its initial concerns were local urban ones, but the focus moved outward to other struggles for participation and democracy in cities elsewhere in the world.

Activity in online social networks has made a contribution to more effective participation in the discussion of local urban problems as well as creating a more sustainable and democratic city. This consolidation of the public sphere has also strengthened governance, with the features of a virtual agora for debating the city, having an impact 
on the real world in the struggle to build a more sustainable vision of the city focused on people, on pedestrians and cyclists, and on switching on the vitality of the street.

What happens in social networks can even attract the attention of administrators, who become cautious and show more concern about accounting for their acts and activities because of mobilisations that occurred online. Individuals and groups posting on blogs and on Facebook have played an important role in the control of official public acts and the democratisation of information, with a positive impact on social control and governance. This new form of activism offers an alternative to the crisis of representative democracy, creating an opening to new spaces for participation which can help in the struggle for fairer, more inclusive and more sustainable cities.

The Grupo Direitos Urbanos | Recife is a benchmark for the diffusion of information and the mobilisation of individuals and groups in the debate on the city and the right to the city. This potential for mobilisation and articulation has contributed to community and social resilience to continue and reformulate strategy within the struggle.

The Movimento Ocupe Estelita showed its potential for resilience and resistance to keep the struggle going, during a range of situations of conflict with the City Council and economic actors from the civil construction sector, most of all following on the violent expulsion of the militants from the Estelita. After their departure from the land plot, the Movement was the key player in a type of resistance and resilience without territorial expression, based in the virtual world and spread throughout the city in the form of walks, meetings and official complaints. The adversity it faced in 2014 strengthened the Movement, which can be considered a political force giving significant expression to the struggle against established power structures in the city of Recife, both political and economic. Its strength draws on both the expertise of older militants and the readiness of younger militants to enter the fray on the ground in order to combat fraudulent, arbitrary decisions and the violation of rights within the struggle for the city.

Cyberactivism turned out to be a major, powerful means of communication and mobilisation, catalysing resilience on the scale of the city. Yet major challenges remain to be faced. The heterogeneous nature of the groups, their interests, political and ideological positions, conflict and disputes over power and leadership are all internal challenges that at times took the wind out of the sails of initiatives and drove members away. The coming municipal elections are raising the temperature and will mean greater pressure from capital to influence the future destiny of the city in accordance with its interests.

Some groups have slowed the pace of their initiatives, while others have reorganised and increased their articulation given a possible revision of the Master Plan and the zoning law (Lei de Uso e Ocupação do Solo). On the other hand, the Movement has been strengthened and acquired allies because of the actions of the Federal Police in its investigation of fraud in the auction of the land intended for the Projeto Novo Recife, as well as the ruling by a federal court striking this auction down. The federal Public Ministry, its local arm in the state of Pernambuco, the federal courts and the groups struggling for the preservation of the Cais Estelita are now acting in concert.

The legal fight continues through the appeals process, but whatever the outcome, developers will face a Movimento Ocupe Estelita that has been strengthened by its struggle. The challenges remain considerable and only time will tell if the Movement 
Edinéa Alcântara é engenheira civil, mestre em Gestão e Políticas Ambientais e doutora em Desenvolvimento Urbano pela Universidade Federal de Pernambuco (UFPE); professora no Instituto Federal de Educação, Ciência e Tecnologia de Pernambuco (IFPE), campus Garanhuns.

E-mail: edinealcantara@ gmail.com

Fátima Furtado é arquiteta e urbanista e mestre em Desenvolvimento Urbano pela Universidade Federal de Pernambuco (UFPE); doutora em Planning Studies pela University of London; professora associada no Departamento de Arquitetura e Urbanismo da Universidade Federal de Pernambuco (DAU/UFPE).

E-mail: fgfurtado@hotmail. com

Circe Gama Monteiro é arquiteta e urbanista pela Universidade Federal do Paraná (UFPR); mestre em Planejamento Urbano e Regional pela Universidade Federal do Rio de Janeiro (UFRJ); doutora em Sociologia Urbana pela University of Oxford, Inglaterra; professora titular no Departamento de Arquitetura e Urbanismo da Universidade Federal de Pernambuco (UFPE).

E-mail: monteiro.circe@ gmail.com

Rubenilda Rosinha Barbosa é graduada em Psicologia, mestre e doutra em Antropologia Cultural pela Universidade Federal de Pernambuco (UFPE); professora adjunta no Departamento de Psicologia da UFPE.

E-mail: rosinha.barbosa@ uol.com.br

Article received on 1 st September 2015 and approved for publication on 2nd December 2015. will be able to retain its characteristics of resilience, rapid response and articulation between the distinct groups of which it is made up in order to overcome future crises and challenges. However that may be, the Movement is an emblem of resistance and urban resilience in the struggle of Recife's citizens for the right to the city.

\section{REFERENCES}

ADGER, W. Social and ecological resilience: Are they related? Progress in Human Geography, v. 24, n. 3, 347-364, Sep. 2000.

ALCÂNTARA, E. Empatando tua Vista: humor e irreverência para criticar a verticalização excessiva nas cidades. Direitos Urbanos | Recife, Recife, 27 Oct. 2014. Available at: <https:// direitosurbanos.wordpress.com/2014/02/27/empatando-tua-vista-humor-e-irreverencia -para-criticar-a-verticalizacao-excessiva-nas-cidades/>. Accessed on: 14th Dec. 2014.

; MONTEIRO, C. The Right to Fight for the City. In: INTERNATIONAL CONFERENCE EVERYDAY LIFE ON THE 21ST CENTURY, 2., 2015, Firenze. Annals... Firezne, jul. 2015.

et al. Cyberactivsm in the struggle for more sustainable cities - a resource for urban social resilience? In: AESOP-ACSP JOINT CONGRESS, 2013, Dublin. Annals... Dublin: AESOP, ACSP, 2013.

et al. Vulnerabilities and resilience of communities living in circumstances of risk. In: MIRA, R. G.; DUMITRU, A. (Org.). Urban Sustainability: Innovative spaces, vulnerabilities and opportunities. A Coruna: Institute for Psychosocial Studies and Research, Deputación da Coruña, 2014. p. 51-72. Available at: <http://www.udc.es/ dep/ps/grupo/varios/urbansus.pdf $>$. Accessed on: 14th Aug. 2015.

ALVES-MAZZOTTI, A. J.; GEWNDSZNAJDER, F. O Método nas Ciências Naturais e Sociais: Pesquisa Quantitativa e Qualitativa. 2. ed. São Paulo: Pioneira Thomson Learning, 2002.

BONANNO, G. Loss, trauma, and human resilience: Have we underestimated the human capacity to thrive after extremely aversive events? American Psychologist, v. 59, n. 1, p. 20-28, Jan. 2004. http://dx.doi.org/10.1037/0003-066x.59.1.20

BROWN, D.; KULIG, J. The concept of resiliency: Theoretical lessons from community research. Health and Canadian Society, v. 4, n. 1, p. 29-52, 1996.

BUSTAMANTE, J. Communicative power, digital ecosystems and digital citizenship. In: SILVEIRA, S. A. (Org.). Cidadania e redes digitais - Citizenship and digital networks. São Paulo: Comitê Gestor da Internet no Brasil, Maracá - Educação e Tecnologias, 2010. p. 11-36. Available at: <http://www.readbag.com/cidadaniaeredesdigitais-br-files-livro>. Accessed on: 9th Jun. 2013.

BUTLER, L.; MORLAND, L.; LESKIN, G. Psychological resilience in the face of terrorism. In BONGAR, B. et al. (Ed.). Psychology of terrorism. New York: Oxford University Press, 2007. p. 400-417.

CAIS Estelita. La demolizione dei diritti. Libera Mottola, 19 jun. 2014. Available at: <http:// www.liberamottola.it/component/content/article/2-non-categorizzato/227-cais-estelita-la-demolizione-dei-diritti.html>. Accessed on: 14th Dec. 2014.

CALDEIRA, T. Cidade de Muros: Crime, Segregação e Cidadania em São Paulo. São Paulo: EDUSP, 2000.

CASTELLS, M. Redes de Indignação e Esperança-Movimentos Sociais na Era da Internet. Rio de Janeiro: Zahar, 2013.

GANOR, M.; BEN-LAVY, Y. Community resilience: Lessons derived from Gilo under fire. Journal of Jewish Communal Service, v. 79, n. 2/3, p. 105-108, Mar. 2003. Available 
at: <http://www.bjpa.org/Publications/details.cfm?PublicationID=1223>. Accessed on: 9th Jun. 2014.

GODSCHALK, D. Urban hazard mitigation: Creating resilient cities. Natural Hazards Review, v. 4, n. 3, p. 136-143, Aug. 2003. http://dx.doi.org/10.1061/(asce)15276988(2003)4:3(136)

GROTBERG, E. Introdução: novas tendências em resiliência. In: MELILLO, A.; OJEDA, E. S. (Org.). Resiliência: descobrindo as próprias fortalezas. Porto Alegre: Artmed, 2005. p. 15-22.

HARVEY, D. Cidades Rebeldes: do direito à cidade à revolução urbana. São Paulo: Martins Fontes, 2014.

INSTITUTO BRASILEIRO DE GEOGRAFIA E ESTATÍSTICA - IBGE. MUNIC Perfil dos municípios brasileiros, 2011. Available at: <http://www.ibge.gov.br/home/presidencia/noticias/noticia_visualiza.php?id_noticia=2260\&id_pagina=1>. Accessed on: 2nd Jun. 2012.

JACOBS, J. The Death and Life of Great American Cities. Nova York: Tne Modern Library Edition, 1993.

KOTLIARENCO, M. A.; CÁCERES, I.; FONTECILLA, M. Estado de arte em resiliência. Washington: OPS/OMS, Fundacion W. K. Kellog, Agencia Sueca de Cooperación Internacional para el Desarrollo, Centro de Estudios y Atención del Niño y la Muje, 1997. Available at: <http://www1.paho.org/hq/dmdocuments/2009/Resil6x9.pdf>. Accessed on: 14th Aug. 2015.

LANDAU, J.; SAUL, J. Facilitando a Resiliência da Família e da Comunidade em Resposta a Grandes Desastres. Pensando Famílias, n. 4, ano 4, p. 56-78, 2002.

LEFEBVRE, H. El Derecho a la Ciudad. Barcelona: Ediciones 62, 1973.

LES OCCUPANTS du mouvement "Ocupe Estelita ", à Recife, capitale du Pernambouc, au Brésil, ont été violemment expulsés par la Police Militaire. Trois activistes ont été arrêtés et un autre grièvement blessé. Oximity, 17 jun. 2014. Available at: <https:// www.oximity.com/article/Les-occupants-du-mouvement-Ocupe-Estel-1>. Accessed on: 14th Dec. 2014.

LINS, L. Reintegração de posse acaba em confusão em Recife. O Globo, Rio de Janeiro, 17 jun. 2014. Available at: <http://oglobo.globo.com/brasil/reintegracao-de-posse-acaba-em-confusao-em-recife-12895696k>. Accessed on: 14th Dec. 2014.

MEIRELES, M. Biógrafo de Clarice Lispector vai doar renda de novo livro para Movimento Ocupe Estelita. O Globo, Rio de Janeiro, 23 nov. 2014. Available at: <http://oglobo. globo.com/cultura/livros/biografo-de-clarice-lispector-vai-doar-renda-de-novo-livro -para-movimento-ocupe-estelita-14634954>. Accessed on: 14th Dec. 2014.

MELILlO, A. Prefácio. In: ______; OJEDA, E. S. (Org.). Resiliência: descobrindo as próprias fortalezas. Porto Alegre: Artmed, 2005. p. 11-13.

; OJEDA, E. S. (Org.). Resiliência: descobrindo as próprias fortalezas. Porto Alegre: Artmed, 2005.

MELITO, L. Anistia Internacional condena desocupação do Cais José Estelita. Portal EBC, Brasília, 17 jun. 2014. Available at: <http://www.ebc.com.br/cidadania/2014/06/ anistia-internacional-condena-desocupacao-do-cais-jose-estelita\#.U6DVoCNYVPw. facebook>. Accessed on: 14th Dec. 2014.

NORRIS, F. H. et al. Community Resilience as a Metaphor, Theory, Set of Capacities, and Strategy for Disaster Readiness. American Journal of Community Psychology, v. 41, n. 1-2, p. 127-150, Mar. 2008. http://dx.doi.org/10.1007/s10464-007-9156-6

OJEDA, E. S. Uma Concepção Latino-americana: a resiliência comunitária. In: MELILLO, A.; OJEDA, E. S. (Org.). Resiliência: descobrindo as próprias fortalezas. Porto Alegre: Artmed, 2005. p. 47-57. 
; AUTLER, L. La resiliencia em la comunidad: um enfoque social. In: GROTBERG, E. H. (Comp.). La resiliencia em el mundo de hoy: cómo superar las adversidades. Barcelona: Gedisa editorial, 2006. p. 271-299.

PF aponta fraude no leilão do terreno do Cais José Estelita, no Recife. Porta G1 Pernambuco, 30 set. 2015. Available at: <http://g1.globo.com/pernambuco/noticia/2015/09/pf-confirma-fraude-no-leilao-do-terreno-do-cais-jose-estelita-no-recife.html>. Acesso em: 13 dez. 2015.

PINTO, L. C. David Harvey participa de evento no Ocupe Estelita. Revista Fórum, São Paulo, 16 nov. 2014. Available at: <http://www.revistaforum.com.br/2014/11/16/david -harvey-participa-de-evento-ocupe-estelita/>. Accessed on: 14th Dec. 2014.

RAVAZZOLA, M. C. Resiliências Familiares. In: MELliLO, A.; OJEDA, E. S. (Org.). Resiliência: descobrindo as próprias fortalezas. Porto Alegre: Artmed, 2005. p. 73-85.

RIBEIRO, L. C. Q. (Coord.). Índice de Bem-Estar Urbano. Rio de Janeiro: Observatório das Metrópoles, 2010. Available at: <http://www.google.com.br/url?sa=t\&rct=$j \& q=\& e s r c=s \&$ source $=w e b \& c d=2 \& v e d=0 C D E Q F j A B \& u r l=h t t p \% 3 A \% 2 F \% 2 F w w w$. observatoriodasmetropoles.net\%2Fdownload\%2Findice_bem_estar_urbano. pdf\&ei=t_Q2Upe6NY7Y8gTXiYHoDw\&usg=AFQjCNHtw9nadrxOKVsP9rH3DL0aC09Lhw\&bvm=bv.52164340,d.eWU>. Accessed on: 16th Sep. 2013.

RODRIGUEZ, D. O humor como indicador de resiliência. In: MELILLO, A.; OJEDA, E. S. (Org.). Resiliência: descobrindo as próprias fortalezas. Porto Alegre: Artmed, 2005. p. $131-138$

SAKAMOTO, L. Caso Estelita: Sabe quem vai ganhar as eleiçôes? Empreiteiras, como sempre. Blog do Sakamoto, São Paulo, 21 jun. 2014. Available at: <http://blogdosakamoto. blogosfera.uol.com.br/2014/06/21/caso-estelita-sabe-quem-vai-ganhar-as-eleicoesempreiteiras-como-sempre/>. Accessed on: 14th Dec. 2014.

SENRA, R. \#SalaSocial: 'Fizeram meu bebê respirar gás lacrimogêneo', diz grávida sobre reintegração no Recife. BBC, 19 jun. 2014. Available at: <http://www.bbc.com/ portuguese/noticias/2014/06/140617_ocupa_estelita_acao_policial_rs.shtml>. Accessed on: 14th Dec. 2014.

SONN, C.; FISHER, A. Sense of community: Community resilient responses to oppression and change. Journal of Community Psychology, v. 26, n. 5, p. 457-472, Sep. 1998. https:// doi.org/10.1002/(sici)1520-6629(199809)26:5\%3C457::aid-jcop5\%3E3.3.co;2-7

TEMOS que nos tornar anticapitalistas, diz David Harvey no Ocupe Estelita. Carta Capital, São Paulo, 24 nov. 2014. Available at: <http://www.cartacapital.com.br/blogs/parlatorio/ temos-que-nos-tornar-anti-capitalistas-diz-david-harvey-no-ocupe-estelita-9906.html>. Accessed on: 14th Dec. 2014.

TRUFFI, R. A batalha pelo Cais José Estelita. Carta Capital, São Paulo, 18 jun. 2014. Available at: $\quad$ http://www.cartacapital.com.br/sociedade/a-batalha-pelo-cais-jose-estelita-8652. html?utm_content=buffer95d51\&utm_medium =social\&utm_source=twitter. com\&utm_campaign=buffer $>$. Accessed on: 14th Dec. 2014.

VANISTENDAEL, S. Cómo crecer superando los percances, resiliencia: capitalizar las fuerzas del individuo. Ginebra: BICE, 1995.

.; ELCOMTE, J. Resiliencia y sentido de vida. In: MELLILO, A.; OJEDA, E. M. S.; RODRÍGUEZ, D. (Comp.). Resiliencia y Subjetividad: los ciclos de la vida. Buenos Aires: Paidós Iberica, 2003. p. 84-91.

WALKER, B. et al. Resilience, adaptability and transformability in social-ecological systems. Ecology and Society, v. 9, n. 2, 2004.

WALSH, F. Fortalecendo a Resiliência Familiar. São Paulo: Roca, 2005.

WATTS, J. Brazilian police criticised over raid on protest camp. The Guardian, 18 jun. 2014. Available at: <https://www.theguardian.com/world/2014/jun/18/brazil-police-raidprotest-camp-recife>. Accessed on: 14th Dec. 2014. 